\title{
Physicians' retention rate and its effective factors in the Islamic Republic of Iran
}

\author{
Elham Ehsani-Chimeh, ${ }^{1}$ Reza Majdzadeh, ${ }^{2}$ Sajad Delavari, ${ }^{3}$ Masoumeh Najafi Gharebelagh, ${ }^{4}$ Satar Rezaei ${ }^{5}$ and Enayatollah Homaie Rad ${ }^{6}$
}

${ }^{1}$ National Institute of Health Research (NIHR), Tehran University of Medical Sciences, Tehran, Islamic Republic of Iran. ${ }^{2}$ Knowledge Utilization Research Center, Community-Based Participatory-Research Center and School of Public Health, Tehran University of Medical Sciences, Tehran, Islamic Republic of Iran. ${ }^{3}$ School of Health Management and Informatics, Shiraz University of Medical Sciences, Shiraz, Islamic Republic of Iran. ${ }^{4}$ School of Public Health, Tehran University of Medical Sciences, Tehran, Islamic Republic of Iran. ${ }^{5}$ Research Center for Environmental Determinants of Health, Kermanshah University of Medical Sciences, Kermanshah, Islamic Republic of Iran. ${ }^{6}$ Social Determinants of Health Research Center, Guilan University of Medical Sciences, Rasht, Islamic Republic of Iran (Correspondence to: Enayatollah Homaie Rad: homaierad@gums.ac.ir).

\begin{abstract}
Background: Migration of physicians from less developed countries to affluent ones has become as one of the major concerns of human resource policy-makers. This leads to problems such as inequity in the distribution of physicians, lack of physicians in less developed areas, as well as an excess of the health workforce in developed environs. Thus, policy-makers aim to increase retention of physicians in their places of origin.

Aims: This study aimed to find those effective factors for the retention of physicians in the Islamic Republic of Iran.

Methods: 30569 records of public sector physicians in 2016 were gathered from the Ministry of Health and Medical Education database, and the retention rate of each province was calculated. Geographic information system (GIS) was used to show retention in each province, and linear and logistic regression analysis were used to determine the effective factors for physicians' retention in the country.

Results: There was a significant relationship between per capita gross domestic product of each province and its retention rate of physicians $(\mathrm{OR}=1.56)$, retention rate of family physicians $(\mathrm{OR}=7.38)$, and retention rate of specialists (OR $=1.59$ ). In addition, relationships were significant for the human development index (all physicians [OR = 1.22], family physicians $[\mathrm{OR}=2.36]$, and specialists $[\mathrm{OR}=1.23]$.). Married physicians, higher paid physicians, and those who worked in headquarters and clinics showed greater willingness to stay in their area of origin.
\end{abstract}

Conclusions: Physicians' retention rate is dependent on both macro and microlevel factors.

Keywords: Retention rate, physicians, specialists, Iran

Citation: Ehsan-Chimeh E; Majdzadeh R; Delavari S; Najafi Gharebelagh M; Rezaei S; Homaie Rad E. Physicians' retention rate and its effective factors in the Islamic Republic of Iran. East Mediterr Health J. 2018;24(9):830-837. https://doi.org/10.26719/2018.24.9.830

Received: 3/01/18; accepted: 08/08/18

Copyright @ World Health Organization (WHO) 2018. Some rights reserved. This work is available under the CC BY-NC-SA 3.o IGO license (https:// creativecommons.org/licenses/by-nc-sa/3.o/igo).

\section{Introduction}

Policy-makers in all countries are concerned about migration. It has been studied and explained by sociologists, economists, demographers and related public health groups within labor markets (1). Zimmerman et al. estimated that 214 million people move internationally and approximately three-quarters of a billion people migrate within their own country (2). This migration affects health care due to impacts on service provision, quality of care, and distribution of human resources for health (HRH) across different parts of the health system, countries, and geographic areas (3).

Unbalanced distribution of health personnel between and within countries is a serious global problem (4). Many countries, especially middle- and low-income countries, have trouble with maldistribution and shortages of HRH $(5,6)$. Overall, it is notable that about one half of the world's population lives in rural and remote areas, yet this half is served by only one quarter of the world's doctors and by less than one third of the world's nurses (7). For example, in Senegal, Dakar is the most urbanized area with more than $60 \%$ of the country's physicians but only $23 \%$ of the total population. In Canada, $24 \%$ of the population is rural, but only $9.3 \%$ of physicians are based in rural areas (2006) (8). Asia, with about half the world's population, has access to only about $30 \%$ of the world's health professionals. Moreover, Africa - with the highest burden of disease - has severe shortages of health professionals and confirms the unbalanced relationship between the need for healthcare and distribution of HRH (5).

One of the most damaging effects of severely imbalanced and under-resourced health systems is the difficulty in producing, recruiting, and retaining health professionals, particularly in remote areas (9). Weakness in the compensation system, low income, poor working conditions, lack of supervision, lack of incentives, lack of equipment and infrastructure, and also the weakness of the health system, all contribute to the immigration of healthcare personnel from remote areas (5). Reviews of factors impacting staff attraction and retention in middleand low-income countries showed that international, national, local (home and social) and work environment 
and individual factors influence attraction and retention (5).

A systematic review of low-income countries showed that financial incentives (90\%), career development $(85 \%)$, hospital or clinic management $(80 \%)$, education and training opportunities (strong motivating affects) and recognition and/or appreciation, either from managers, colleagues, or the community $(70 \%)$ could motivate health workers and increase retention (10). Because this is global problem, the World Health Organization (WHO) suggested recommendations to improve the recruitment and retention of health workers in remote and rural areas in four major categories: education, regulation, financial incentives for health workers in remote and rural areas, and professional and personal support for health workers in remote and rural areas (8).

In the Islamic Republic of Iran, the distribution of $\mathrm{HRH}$ is not equitable between and within provinces, especially in deprived areas (11,12). For example, a survey using Gini and Atkinson measures of inequality for general physicians (GPs) from 2006 to 2011 showed a lower status when taking into account the province's health needs. Another study showed that health workforce distribution had varied widely in the country, with deprived provinces particularly negatively impacted. Lower Gini coefficients in 2010-2012 were due primarily to the increase in health workforce in high-income provinces, while deprived provinces continued to face serious problems $(13,14)$.

Inappropriate and unequal distribution of health workforce is a major concern for the health management sector (15). It would appear that at least five factors influence the distribution of $\mathrm{HRH}$ in the Islamic Republic of Iran, namely the health service, geography, demographics, socioeconomic development of the area in question, and personal factors (16). Because of increasing numbers of health sciences students during the past two decades $(13,17)$, it is important to study their distribution and retention across the country in order to develop policies on decreasing inaccessibility to $\mathrm{HRH}$ and also ensure the efficient and effective use of resources. Thus, it is relevant to know the proportion of health workers who operate in their home cities and provinces, compared to the number that emigrates to other areas and the reasons for this. Since the majority of HRH is employed by the Iranian Ministry of Health and Medical education (MoHME), this study focused on personnel internal immigration data gained from the ministry. This study provides evidence for $\mathrm{HRH}$ in different provinces and assists policy-makers in the revision of compensation and motivation systems to improve the retention of $\mathrm{HRH}$ personnel in deprived provinces.

\section{Methods}

\section{Individual level data}

Data for public sector physicians, which includes general physicians and specialists, were gathered from MoHME's database in 2016. The database, called "AZERAKHSH", contains information on all MoHME personnel in its headquarter and all medical universities controlled by the office of human resources management. The database is used to monitor the number of health personnel, location, retirement, staff transfers, and includes individual, occupational and salary information. From the data sources, all names were removed for ethical consideration. After screening of non-related samples, 30569 records remained. Non-related samples contained data for 158 physicians for whom information on place of birth or province of work were not available. Database information included gender, educational level, specialty, monthly salary, marital status, first three digits of national ID number, province of work and employment position of each physician. It should be emphasize that studied records include all general physicians and specialists who are affiliated to MoHME with all types of contracts (short-time and permanent).

\section{Provincial level data}

To analyze the relationship between provincial factors and HRH retention rates, provincial data were gathered, consisting of per capita gross provincial product (per capita GPP), Human Development Index (HDI) for each province (2016), life expectancy at birth (2016), provincial adult literacy rate (2016), and per capita GPP after adjustment for gas and oil sales (2016). Provincial data were sourced from the Iranian Statistical Centre database.

\section{Statistical analysis}

To define retention of physicians, the province of birth was compared with the province of employment. If the physician was working in his/her province of birth, it was considered that he/she has remained in their province or birth. The "retention at place of birth" rate was calculated for each province using the following formula:

$$
\mathrm{NR}_{\mathrm{i}}=\mathrm{Wb}_{\mathrm{i}}-\mathrm{Wo}_{\mathrm{i}}
$$

$\mathrm{NR}_{\mathrm{i}}=$ net retention of the province.

$i$ and $\mathrm{Wb}_{\mathrm{i}}=$ number of physicians born in the province $i$ and worked in other provinces.

$\mathrm{Wo}_{\mathrm{i}}=$ number of physicians born in other provinces and worked in province $\mathrm{i}$.

The net retention rate (NRR) for each province (i) was calculated using the following formula:

$\mathrm{NRi}=$ net retention

$$
\mathrm{NRRi}=\frac{N R i}{W R i}
$$

$\mathrm{WRi}$ = number of physicians who worked in each province (17-19).

The index "i" runs from 1 to 31. NRR were calculated for general physicians, family physicians, and specialists, respectively. NRR GIS maps were created for each province and linear regression analysis was used to show the effective factors for NRR in each province. The relationship between NRR, Human Development Index (HDI) and GDP for each province was calculated using ordinarily least square (OLS) regression models. For this purpose, three different models were utilized with dependent variables of NRR for family physicians, 
specialists and general physicians. Independent variables of these models contained provincial GDP and HDI figures. Lastly, a mixed effect two-level logistic regression was estimated to determine effective factors of retention of physicians at both the provincial and individual level. To calculate physician retention, two values $(0=$ migrate to provinces outside place of birth, $1=$ remaining in place of birth) were used. Gender, marital status, salary, specialty, and education level were added as explanatory variables at the individual level, and GDP and HDI were added as explanatory variables at the provincial level. Variance inflation factor (VIF) test was used to show the level of co-linearity between explanatory variables. Goodness of fit statistics of the model contain Log likelihood and Wald test were also estimated. All analysis was done using STATA MP version 14 software (College Station, Texas, USA).

\section{Results}

Figure 1 indicates the GIS map of retention of physicians in each Iranian province. Larger circles illustrate higher NRR. Alborz province (closest to the capital Tehran) and Southern provinces had the lowest retention rates, while Tehran and the northern provinces (Caspian Sea border) had the highest retention rates. Findings were also similar for specialists and family physicians' retention rates.
In addition, the HDI of each province was colour coded in the map and categorized into 5 groups from high to low. As indicated in Figure 1, provinces with larger circles have brighter colours, indicating that provinces with higher levels of HDI have higfher NRRs.

Table 1 indicates the results of the regression on the relationship between NRR of physicians versus HDI and GDP. HDI and GDP per capita were both positively significant (HDI coefficient: all physicians: 0.20 , family physicians: 0.86 , specialists: 0.21 ) (GDP coefficient: all physicians: 0.45 , family physicians: 2.03 , specialists: 0.47 ) Therefore, it is indicated that in provinces with higher HDI and per capita GPP, net retention rate was higher.

Table 2 indicates the results of the mixed effect multilevel logistic model for analyzing effective factors of retention in place of birth at the individual level. Sex did not have any significant relationship with retention (OR $=0.9721, P=0.285)$. The likelihood of retention of married physicians was higher $(\mathrm{OR}=1.33, P<0.001)$. Specialists $(\mathrm{OR}=0.61, P=<0.001)$ and sub-specialist physicians $(\mathrm{OR}=0.63, P<0.001)$ show greater migration to other provinces compared to GPs. Physician salary OR was $1.00(P=0.000)$. Therefore, salary is not an effective factor for retention. In addition, physicians with positions at MoHME headquarters $(\mathrm{OR}=1.19, P=0.010)$ and clinics $(\mathrm{OR}=1.56, P<0.001)$ were more likely to remain in their

Figure 1 Geographic Information System (GIS) map to show retention of all physicians, family physicians, and specialists. Larger circles show higher net retention rate (NRR); provinces with more lighter colours had higher human development index (HDI) scores.

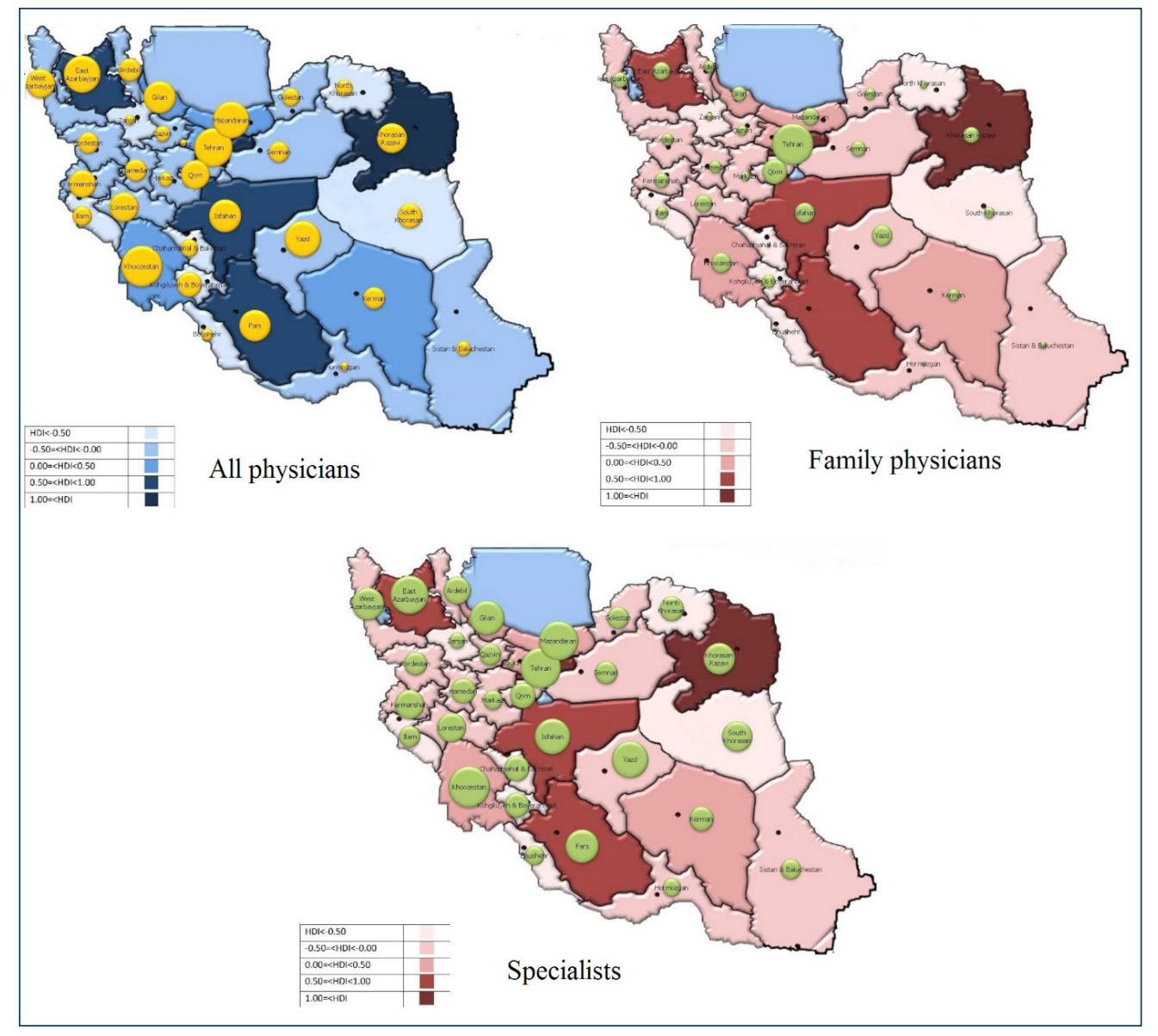




\begin{tabular}{|c|c|c|c|c|c|c|}
\hline & \multirow[t]{2}{*}{ Coefficient } & \multirow[t]{2}{*}{$\mathrm{SE}^{*}$} & \multirow[t]{2}{*}{ P-value } & \multicolumn{2}{|c|}{ 95\% Confidence interval } & \multirow[t]{2}{*}{$\mathbf{R}^{2}$} \\
\hline & & & & Lower & Upper & \\
\hline All physicians & $N=30569$ & & & & & 0.551 \\
\hline HDI & 0.20 & 0.05 & $<0.001$ & 0.10 & 0.30 & \\
\hline GDP (million Rls) & 0.45 & 0.12 & 0.001 & 0.20 & 0.68 & \\
\hline Family physicians & $N=2710$ & & & & & 0.715 \\
\hline HDI & 0.86 & 0.11 & $<0.001$ & 0.63 & 1.10 & \\
\hline GDP (million Rls) & 2.03 & 0.24 & $<0.001$ & 1.55 & 2.52 & \\
\hline Specialists & $N=15074$ & & & & & 0.448 \\
\hline HDI & 0.21 & 0.05 & $<0.001$ & 0.10 & 0.32 & \\
\hline GDP (million Rls) & 0.47 & 0.12 & 0.001 & 0.22 & 0.71 & \\
\hline
\end{tabular}

*SE: Standard Error

birthplace compared to hospital physicians. The results of VIF test showed low co-linearity between explanatory variables (Mean VIF statistics $=1.46)$. Income $(\mathrm{VIF}=$ 2.12), place of work (rural health centres) $(\mathrm{VIF}=2.00)$ and academic degree level (specialist) (VIF $=2.27$ ) had the highest level of co-linearity with other variables. Wald $\chi 2$ of model was $2516.32(P=0.000)$ and Psuedo- $R^{2}$ (goodness of fit) was 0.0636 . Log likelihood of the model was -18537.968.

\section{Discussion}

Physicians at all levels of specialism are an essential $\mathrm{HRH}$ component. Our findings indicate that the level of provincial development is an effective factor for physician retention rate. However, low retention rates in less developed rural areas are an important issue that some medical schools are trying to address. While some studies suggested reform in medical education could improve retention in rural areas (21-23), other factors such as development levels of service and demographic factors are critical, but are rarely addressed in studies (5).

The present study aimed at finding the relationship between demographic factors, provincial development levels and physician retention. Analyzed data and GIS maps reveal that the higher the development level of a province, the higher the retention rate. Similar results were reported in a survey of eight low- and middleincome countries in Asia and Africa. In addition, it was found that work environment resources, location livability and employment conditions were non-medical factors that could affect intention to work in rural areas or to leave (24). Physicians, like other professionals, look for better living standards and professional development, This issue plays a significant role in their retention rate in rural areas $(25,26)$. Thus, it is logical that HDI and provincial development levels have a significant relationship with retention rates. According to this finding, it is suggested that improving infrastructure in all provinces and regions could improve $\mathrm{HRH}$ retention.

At the individual level, gender is not a primary factor in retention while marital status is significant. The relation between demographic factors and retention in rural areas is hotly debated in the literature. Certain studies consider demographic factors as predictors of retention in rural areas $(21,27)$, while others report that male physicians have a greater tendency to work in rural settings $(22,28)$. However, our findings indicated that there were no gender differences when considering the tendency to stay in one's place of birth. On the contrary, many studies found that demographic variables such as marital status and gender did not affect retention or practice in rural settings (29-31). While there is not a clear relationship between gender and retention, according to current findings it could be concluded that development levels are more important than other factors as presented in Table 1. However, when considering other research findings, it can be concluded that area development could affect cultural and literacy levels and therefore quality of life (27).

Another individual factor that affects retention is salary, which is the main strategy for improving retention rates in rural areas (32); low salaries hinder retention $(5,7,22,33)$. In the Islamic Republic of Iran, salaries are calculated on perceived provincial deprivation levels, with lower developed provinces offering higher salaries, yet payment can be irregular and still not at an attractive level. However, our findings indicated that salary did not change the tendency of physicians to remain in their place of birth.

This study did have a number of limitations. Available data did not cover all variables that could affect retention and data did not present total payments to physicians. However, many studies shows that the payment system and income of physicians play an important role in retention (5).

Results showed that specialists and subs-specialists have greater opportunities to migrate to other provinces when compared to GPs, who have positions in headquarters and clinics, tend to stay; thus, it can be concluded that GPs prefer job security. However, specialists tend to enjoy higher incomes in areas with higher levels of social welfare and therefore emigrate to 


\begin{tabular}{|c|c|c|c|c|c|}
\hline & \multirow{2}{*}{$\begin{array}{c}\text { Adjusted Odds } \\
\text { Ratio }\end{array}$} & \multirow[t]{2}{*}{ P-value } & \multicolumn{2}{|c|}{$95 \%$ confidence interval } & \multirow[t]{2}{*}{ number } \\
\hline & & & Lower & Upper & \\
\hline Sex (female) & Ref. & & & & 14048 \\
\hline Sex (male) & 0.972 & 0.285 & 0.923 & 1.022 & 16517 \\
\hline Marriage (single) & Ref. & & & & 6205 \\
\hline Marriage (married) & 1.337 & $<0.001$ & 1.253 & 1.426 & 24255 \\
\hline \multicolumn{6}{|l|}{ Academic Degree } \\
\hline General Physician & Ref. & & & & 15493 \\
\hline Specialist & 0.616 & $<0.001$ & 0.572 & 0.663 & 12647 \\
\hline Subspecialists & 0.633 & $<0.001$ & 0.576 & 0.707 & 2525 \\
\hline Salary (million Rls) & 1.000 & $<0.001$ & 1.000 & 1.011 & \\
\hline \multicolumn{6}{|l|}{ Place of work } \\
\hline Hospital & Ref. & & & & 11883 \\
\hline Rural h. house & 0.971 & 0.603 & 0.891 & 1.061 & 5546 \\
\hline University/faculty & 1.012 & 0.735 & 0.921 & 1.101 & 5403 \\
\hline Headquarter & 1.194 & 0.016 & 1.034 & 1.376 & 1110 \\
\hline Clinic & 1.562 & $<0.001$ & 1.257 & 1.956 & 446 \\
\hline Urban h. house & 1.132 & 0.008 & 1.033 & 1.244 & 1834 \\
\hline Others (emergency services, etc.) & 0.624 & $<0.001$ & 0.553 & 0.694 & 4342 \\
\hline GDP & 0.993 & $<0.001$ & 0.992 & 0.993 & \\
\hline HDI level & 1.156 & $<0.001$ & 1.132 & 1.173 & \\
\hline Constant variable & 1.88 & $<0.001$ & 1.719 & 2.056 & \\
\hline Variance of provincial level & 0.015 & $<0.001$ & & & \\
\hline Variance of provincial level (null model) & 0.023 & & & & \\
\hline Psuedo- $R^{2}=0.0636$ & & & & & \\
\hline
\end{tabular}

more developed provinces (23).

According to our findings and studies from Thailand, increasing the number of medical students in areas with lower levels of HDI, registering native-born students coupled with recruitment and training for rural practice could be an appropriate policy for increasing retention in deprived and rural areas (7,34,35). In addition, using appropriate motivation and financial incentives, and improving working conditions are major policies that were not investigated in this research but are proposed in many other studies (36).

In the study, we relied on the accuracy of data collected at the country level. Any issue related to data gathering may reduce the reliability of the findings. For this, we suggest a comprehensive research that collects larger amounts of data for analysis. This could be done through questionnaires and self-reporting by physicians. In addition, the definition of retention was based on place of birth, whereas in some studies retention might be defined by the first place of employment. Ease of accessibility to comprehensive data for place of birth via the Iranian birth registration system of Iran influenced our decision for this definition in this study. Furthermore, we did not access data for those physicians who work in organizations other than MoHME and thus we were not able to analyze retention rates for them. Another important affecting factor for physician retention is dual practice, which was not considered in this study due tolack of information about the dual practice statuses of studied physicians. In addition, because of using secondary data, we could not analyze personal factors such as personal attitudes and motivation. The other important issue is differences in retention within provinces; it is assumed there is more inequality in physicians' retention within provinces' districts, and this should be a topic for further research.

\section{Conclusion}

Developmental levels and their related indicators (HDI and GDP) are factors that could affect retention of physicians of all specialisms. The research showed that this is a key factor for the retention of GPs. Thus, improvement in infrastructure in all developing provinces could result in better retention and better access to healthcare facilities by population.

Funding: None.

Competing interests: None declared. 


\section{Taux de fidélisation des médecins et facteurs efficaces en République islamique d'Iran}

\section{Résumé}

Contexte : La migration des médecins depuis les pays moins développés vers les pays riches est devenue l'une des principales préoccupations des responsables de l'élaboration de politiques en matière de ressources humaines. Cette situation entraîne des problèmes tels qu'une inégalité dans la répartition des médecins, un manque de médecins dans les régions moins développées, ainsi qu'un trop grand nombre de personnels de santé dans les régions développées. C'est pourquoi les responsables de l'élaboration de politiques visent à améliorer la fidélisation des médecins dans leurs régions d'origine.

Objectifs : La présente étude avait pour objectif de trouver les facteurs qui permettent de fidéliser les médecins en République islamique d'Iran.

Méthodes : En 2016, 30569 dossiers de médecins du secteur public ont été consultés à partir de la base de données du ministère de la Santé et de l'Enseignement médical, et le taux de fidélisation a été calculé pour chaque province. Un système d'information géographique a été utilisé pour indiquer la fidélisation dans chaque province, et une analyse de régression linéaire et logistique a été appliquée pour déterminer les facteurs permettant de fidéliser les médecins dans le pays.

Résultats : Une relation significative a été constatée entre le produit intérieur brut par habitant et le taux de fidélisation des médecins $(\mathrm{OR}=1,56)$, le taux de fidélisation des médecins de famille $(\mathrm{OR}=7,38)$ et le taux de fidélisation des spécialistes $(\mathrm{OR}=1,59)$ de chaque province. En outre, des liens importants ont été remarqués avec l'indice de développement humain (tous les médecins [OR $=1,22]$, les médecins de famille [OR $=2,36]$ et les spécialistes [OR $=1,23]$ ). Les médecins mariés, les médecins mieux rémunérés et ceux qui officient dans une et dans des cliniques ont manifesté une plus grande volonté de rester dans leur région d'origine.

Conclusions: Le taux de fidélisation des médecins dépend à la fois de facteurs relevant des niveaux macro et micro.

$$
\text { الهام احساني-شيمة، رضا بجد زادة، سجاد الأطباء والعو امل الفعالة في جمهورية إيران الإسلامية، معصومة نجفي قرة بلاغ، ستار رضايي، عنايت إله همائي راد }
$$

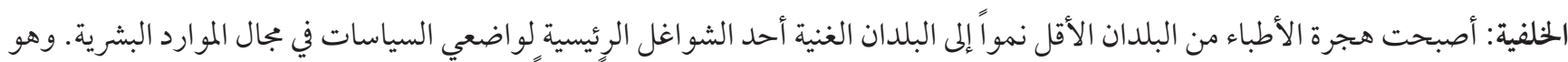

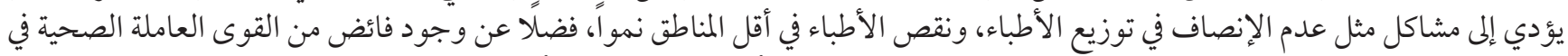

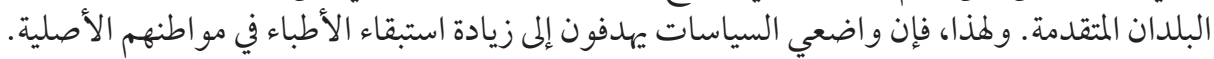

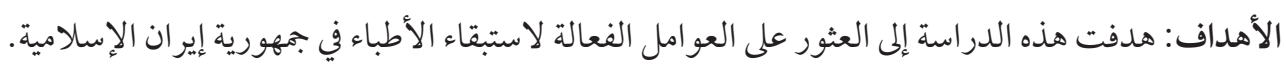

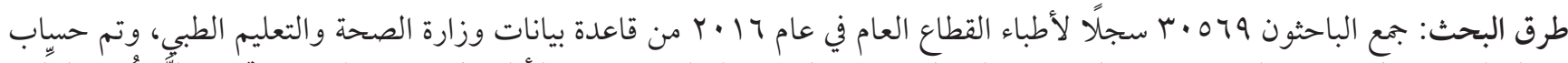

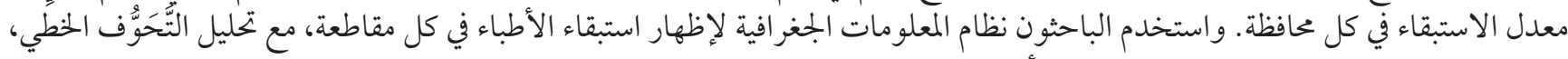
واللوجستي لتحديد العوامل الفعالة في استبقاء الأطباء في البلاد.

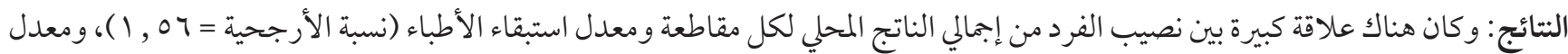

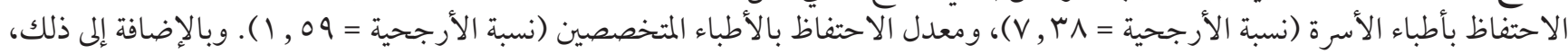

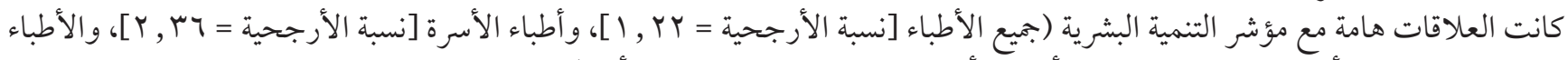

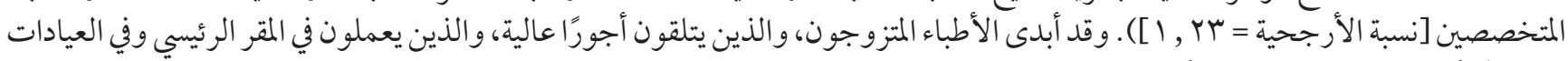
استعدادًا أكبر للبقاء في مناطقهم الأصلية. الاستنتاجات: تعتمد معدلات استبقاء الأطباء على عو امل ذات مستويات كبرى وعو امل أخرى ذات مستويات صغرى.

\section{References}

1. Stilwell B, Diallo K, Zurn P, Dal Poz MR, Adams O, Buchan J. Developing evidence-based ethical policies on the migration of health workers: conceptual and practical challenges. Hum Resour Health. 2003 10 28;1(1):8. https://doi.org/10.1186/1478-4491-1-8 PMID:14613524

2. Zimmerman C, Kiss L, Hossain M. Migration and health: a framework for 21st century policy-making. PLoS Med. 2011 May;8(5):e1001034. https://doi.org/10.1371/journal.pmed.1001034 PMID:21629681

3. Diallo K. Data on the migration of health-care workers: sources, uses, and challenges. Bull World Health Organ. 2004 Aug;82(8):601-7. PMID:15375450 
4. Dussault G, Franceschini MC. Not enough there, too many here: understanding geographical imbalances in the distribution of the health workforce. Hum Resour Health. 200605 27;4(1):12. https://doi.org/10.1186/1478-4491-4-12 PMID:16729892

5. Lehmann U, Dieleman M, Martineau T. Staffing remote rural areas in middle- and low-income countries: a literature review of attraction and retention. BMC Health Serv Res. 2008 01 23;8(1):19. https://doi.org/10.1186/1472-6963-8-19 PMID:18215313

6. Mobaraki H, Hassani A, Kashkalani T, Khalilnejad R, Chimeh EE. Equality in distribution of human resources: the case of Iran's Ministry of Health and Medical Education. Iran J Public Health. 2013 o1 1;42(1) Supple1:161-5. PMID:23865035

7. Dolea C. Increasing access to health workers in remote and rural areas through improved retention: global policy recommendations. Geneva: World Health Organization; 2010.

8. Buchan J, Couper ID, Tangcharoensathien V, Thepannya K, Jaskiewicz W, Perfilieva G, et al. Early implementation of WHO recommendations for the retention of health workers in remote and rural areas. Bull World Health Organ. 2013 Nov 1;91(11):834-40. https://doi.org/10.2471/BLT.13.119008 PMID:24347707

9. Bahadori M, Raadabadi M, Teymourzadeh E, Yaghoubi M. Confirmatory factor analysis of the herzberg job motivation model for workers in the military health organizations of Iran. Journal of Military Medicine. 2015;17(2):65-71.

10. Willis-Shattuck M, Bidwell P, Thomas S, Wyness L, Blaauw D, Ditlopo P. Motivation and retention of health workers in developing countries: a systematic review. BMC Health Serv Res. 200812 4;8(1):247. https://doi.org/10.1186/1472-6963-8-247 PMID:19055827

11. Abbasi M, Hasoumi M, Mohamadi E, Asadi H. Analysis of the relationship between distributions of health sector inputs and health outcomes in Iran; using Gini coefficient. Bioethics Journal. 2016;4(12):65-79.

12. Homaie Rad E, Ghaisi A, Arefnezhad M, Bayati B. Inequalities of general physicians and specialists visits' utilization and its determinants in Iran: a population based study. Int J Hum Rights Health. 2015;8(3):125-31. https://doi.org/10.1108/ IJHRH-12-2014-0032

13. Honarmand R, Mozhdehifard M, Kavosi Z. Geographic distribution indices of general practitioners, midwives, pediatricians, and gynecologists in the public sector of Iran. Electron Physician. 201706 25;9(6):4584-9. https://doi.org/10.19082/4584 PMID:28848634

14. Haghdoust Aliakbar KA, Ashrafi Ahmad, Sadeghirad Behnam. Geographical Distribution of different types of Physicians in Iran and its Provincial inequity. Journal of medical Council of Iran. 2009;28(4):8.

15. Hassani SA, Mobaraki H, Bayat M, Mafimoradi S. Right place of human resource management in the reform of health sector. Iran J Public Health. 2013;42(1):56-62. PMID:23515234

16. Chimeh EE, Behbahani AA. Factors Affecting the Service Delivery Locations of Newly Graduated Iranian General Practitioners. Iran Red Crescent Med J. 2016;19(2)

17. Simforoosh N, Ziaee SAM, Tabatabai SH. Growth trends in medical specialists education in Iran; 1979- 2013. Arch Iran Med. 2014 Nov;17(11):771-5. PMID:25365619

18. Hagedorn LS. How to define retention. College student retention formula for student success. 2005:90-105.

19. Kugler AD, Sauer RM. Doctors without borders? Relicensing requirements and negative selection in the market for physicians. J Labor Econ. 2005;23(3):437-65. https://doi.org/10.1086/430283

20. Society for Human Resource Management Retention. How do I calculate retention? Is retention related to turnover? United States2016.

21. Delavari S, Arab M, Rashidian A, Nedjat S, Souteh RG. A Qualitative Inquiry Into the Challenges of Medical Education for Retention of General Practitioners in Rural and Underserved Areas of Iran. J Prev Med Public Health. 2016 Nov;49(6):386-93. https:// doi.org/10.3961/jpmph.16.062 PMID:27951631

22. Qing Y, Hu G, Chen Q, Peng H, Li K, Wei J, et al. Factors that influence the choice to work in rural township health centers among 4,669 clinical medical students from five medical universities in Guangxi, China. J Educ Eval Health Prof. 2015 07 10;12:40. https://doi.org/10.3352/jeehp.2015.12.40 PMID:26268830

23. Vujicic M, Zurn P, Diallo K, Adams O, Dal Poz MR. The role of wages in the migration of health care professionals from developing countries. Hum Resour Health. 200404 28;2(1):3. https://doi.org/10.1186/1478-4491-2-3 PMID:15115549

24. Silvestri DM, Blevins M, Wallston KA, Afzal AR, Alam N, Andrews B, et al. Nonacademic Attributes Predict Medical and Nursing Student Intentions to Emigrate or to Work Rurally: An Eight-Country Survey in Asia and Africa. 2017.

25. Chhea C, Warren N, Manderson L. Health worker effectiveness and retention in rural Cambodia. Rural Remote Health. 2010 JulSep;10(3):1391. PMID:20701412

26. Arah OA, Ogbu UC, Okeke CE. Too poor to leave, too rich to stay: developmental and global health correlates of physician migration to the United States, Canada, Australia, and the United kingdom. Am J Public Health. 2008 Jan;98(1):148-54. https://doi. org/10.2105/AJPH.2006.095844 PMID:17954520

27. Buykx P, Humphreys J, Wakerman J, Pashen D. Systematic review of effective retention incentives for health workers in rural and remote areas: towards evidence-based policy. Aust J Rural Health. 2010 Jun;18(3):102-9. https://doi.org/10.1111/j.14401584.2010.01139.x PMID:20579020

28. Jones MP, Humphreys JS, Nicholson T. Is personality the missing link in understanding recruitment and retention of rural general practitioners? Aust J Rural Health. 2012 Apr;20(2):74-9. https://doi.org/10.1111/j.1440-1584.2012.01263.x PMID:22435767 
29. Odhiambo J, Rwabukwisi FC, Rusangwa C, Rusanganwa V, Hirschhorn LR, Nahimana E, et al. Health worker attrition at a rural district hospital in Rwanda: a need for improved placement and retention strategies. Pan Afr Med J. 2017 07 4;27:168. https://doi. org/10.11604/pamj.2017.27.168.11943 PMID:28904696

30. Dossajee H, Obonyo N, Ahmed SM. Career preferences of final year medical students at a medical school in Kenya-A cross sectional study. BMC Med Educ. 201601 11;16(1):5. https://doi.org/10.1186/s12909-016-0528-1 PMID:26754206

31. Amiresmaili M, Khosravi S, Feyzabadi VY. Factors Affecting Leave out of General Practitioners from Rural Family Physician Program: A Case of Kerman, Iran. Int J Prev Med. 2014 Oct;5(10):1314-23. PMID:25400891

32. Grobler L, Marais BJ, Mabunda S. Interventions for increasing the proportion of health professionals practising in rural and other underserved areas. Cochrane Database Syst Rev. 201506 30; (6):CDoo5314. PMID:26123126

33. Goel S, Angeli F, Bhatnagar N, Singla N, Grover M, Maarse H. Retaining health workforce in rural and underserved areas of India: What works and what doesn't? A critical interpretative synthesis. Natl Med J India. 2016 Jul-Aug;29(4):212-8. PMID:28050999

34. Brooks RG, Walsh M, Mardon RE, Lewis M, Clawson A. The roles of nature and nurture in the recruitment and retention of primary care physicians in rural areas: a review of the literature. Acad Med. 2002 Aug;77(8):790-8. https://doi.org/10.1097/00001888200208000-00008 PMID:12176692

35. Straume K, Shaw DM. Effective physician retention strategies in Norway's northernmost county. Bull World Health Organ. 2010 May;88(5):390-4. https://doi.org/10.2471/BLT.09.072686 PMID:20461137

36. Dolea C, Stormont L, Braichet J-M. Evaluated strategies to increase attraction and retention of health workers in remote and rural areas. Bull World Health Organ. 2010 May;88(5):379-85. https://doi.org/10.2471/BLT.09.070607 PMID:20461133 